\title{
Multidrug Resistant Bacteria in Pediatric Patients: A Therapeutic Nightmare
}

\author{
Archana Chintaman Choure ${ }^{1 *}$, Vaishali B. Dohe ${ }^{2}$, Swati S. Mudshingkar ${ }^{2}$, \\ Meghana S. Palewar ${ }^{2}$ and Renu R. Bhardwaj ${ }^{2}$ \\ ${ }^{1}$ Department of Microbiology, Smt Kashibai Navale Medical College \& General Hospital, \\ Pune-411041, India \\ ${ }^{2}$ Department of Microbiology B. J. Govt. Medical College Pune, India \\ *Corresponding author
}

Keywords

Multidrug resistant bacteria, Pediatric patients, Antibiotic

Article Info

Accepted:

18 September 2018

Available Online:

10 October 2018

\section{A B S T R A C T}

Bacterial infections caused by multidrug resistant bacteria (MDR) are a constant challenge for physicians throughout the world. We processed 451 clinical samples (blood, urine, pus and body fluids) from pediatric patients during the period of July'11 to Oct'11 in Sassoon General Hospital, Pune. Objective is to identify the bacterial isolates from different clinical specimens and study their antibiotics susceptibility pattern. Bacterial infections could be detected in $155(34.4 \%)$ patients. These bacteria were isolated from blood $(61 \%)$, urine (23\%), pus (14\%) and body fluid (2\%). $64.6 \%$ of the infections were from the ward and $35.5 \%$ from NICU. $88.4 \%$ were gram negative bacilli and $11.7 \%$ were gram positive cocci. The most common gram negative bacilli isolated were Pseudomonas aeruginosa (22\%) followed by Escherichia coli (15.5\%) and Klebsiella pneumoniae (15.5\%). $62 \%$ of the isolates were MDR, of which 33\% were carbapenemase producers. Among the nonfermenters $3.3 \%$ organisms were resistant to all drugs including colistin and polymyxin B. Increasing drug resistant organisms emerging in health care settings is prolonging hospital stay and increasing the cost of health care. So there is an urgent need to formulate guidelines and rationalize the use of antibiotics curtail this pandemic of drug resistance.

\section{Introduction}

Patients admitted to NICU and PICU are at more risk to have infections with multi drug resistant bacteria. Infections caused by multidrug resistant (MDR) bacteria constantly challenge physicians globally (Suchada Sritippayawan et al., 2009). MRSA and ESBL producers are continuously increasing with time due to development of different drug resistant mechanisms by bacteria. Carbapenemase producing organisms are increasing all over the world and unfortunately some bacteria are even resistant to polymyxin and colistin limiting treatment options (Grisaru-Soen et al., 2007; Asensio et al., 2000).

The main aim and objectives of this study includes to study the bacteriological profile of various infections in pediatric patients. And also to study the antimicrobial susceptibility patterns of bacterial isolates. 


\section{Materials and Methods}

Period-July 2011 to October 2011.

Location-Pediatric ward and NICU of Sassoon General Hospital, Pune.

Specimens-451 clinical samples of pus, urine, blood \& body fluids cultured

Isolates were identified by standard microbiological procedures (Collee et al., 2012; Collee et al., 2012; Forbes et al., 2007; Forbes et al., 2007).

Antimicrobial susceptibility test done by Kirby Baur's disc diffusion method as per CLSI 2011

\section{Results and Discussion}

Overall culture positivity rate was $34.4 \%$ in our study, which was more than (Tsering et al., 2011) 22\% and (Ramesh Bhat et al., 2011) 22.8\%. Whereas in (Prasad Gunjal et al., 2012) study it was $51.69 \%$.

In our study positive blood cultures were $61 \%$, which is near to (Douglas et al., 2004) 52\% but more than (Uslan et al., 2007) 38\% and (Sucu et al., 2005) 46\%.

Predominant isolate on culture in our study was Gram negative bacilli $88.4 \%$, which is consistent with Tsering et al., (2011) 61\%, Ramesh Bhat et al., (2011), 60\% and Gunjal et al., (2012) 61.9\%.

Among these bacteria Pseudomonas aeruginosa was the most common 21.9\% whereas Enterobacter $15.38 \%$, Klebsiella pneumoniae $26.66 \%$ and E. coli $44.6 \%$ were isolated Tsering et al., (2011), Ramesh Bhat et al., (2011) and Gunjal et al., (2012) respectively.

Among gram positive isolates MSSA was most common $6.45 \%$ followed by MRSA $1.93 \%$.

Multi drug resistant isolates were $62 \%$ of which $33 \%$ were carbapenemase producers, $3.3 \%$ were Non-fermenter resistant to colistin and $1.93 \%$ were MRSA.

Prevalence of bacterial infection in pediatric patients was $34.4 \%$.

\section{Chart-1 Sample wise distribution of isolates $(n=155)$}

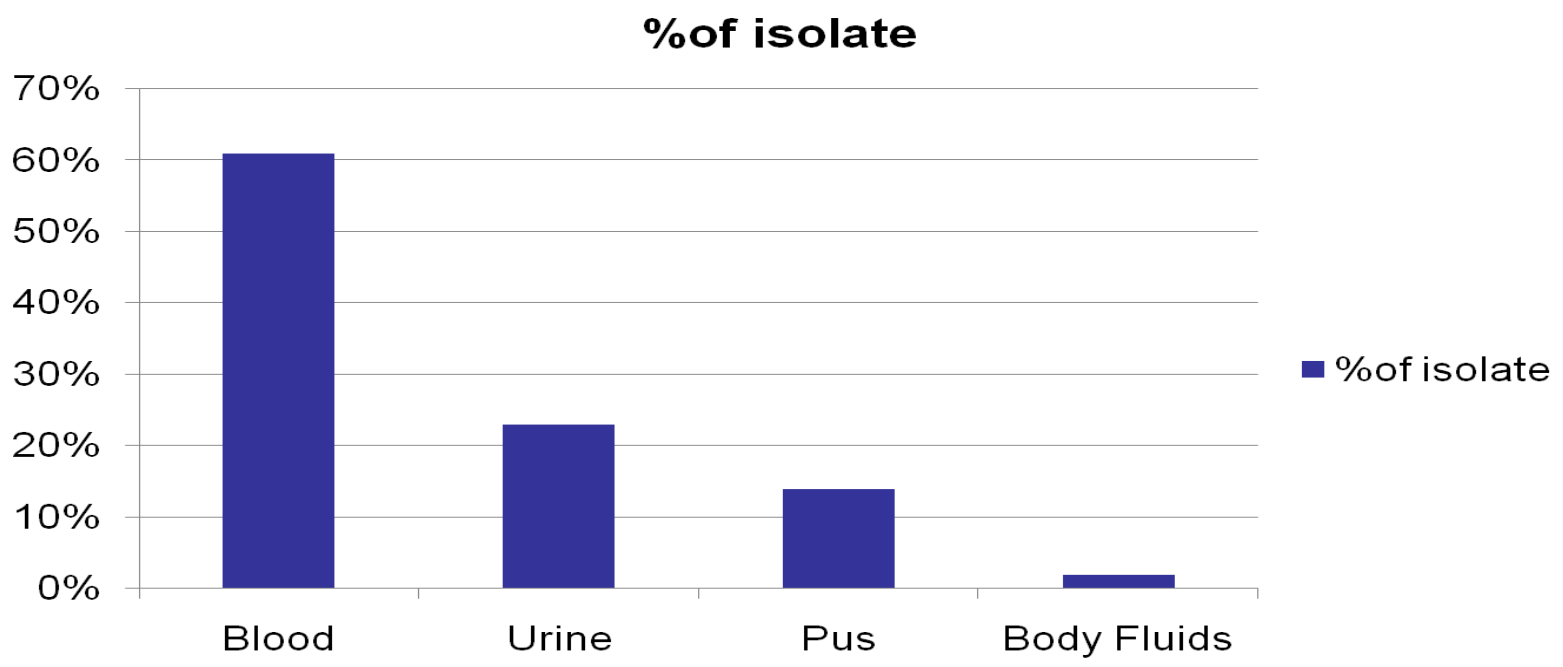


Table.1 Distribution of all isolates $(\mathrm{n}=155)$

\begin{tabular}{|l|}
\hline Organism \\
\hline Gram negative bacilli \\
\hline Pseudomonas aeruginosa \\
\hline E.coli \\
\hline Klebsiella pneumoniae \\
\hline Acinetobacter spp. \\
\hline Citrobacter spp. \\
\hline Enterobacter spp. \\
\hline Proteus \\
\hline Non-fermenter \\
\hline Brevundimonas vesicularis \\
\hline Gram positive cocci \\
\hline MSSA \\
\hline MRSA \\
\hline Streptococcus spp. \\
\hline Enterococcus spp. \\
\hline
\end{tabular}

\begin{tabular}{|c|c|}
\hline No. of isolates & \% of isolates \\
\hline $\mathbf{1 3 7}$ & \\
\hline 34 & $21.93 \%$ \\
\hline 24 & $15.5 \%$ \\
\hline 24 & $15.5 \%$ \\
\hline 23 & $14.83 \%$ \\
\hline 12 & $7.74 \%$ \\
\hline 10 & $6.45 \%$ \\
\hline 7 & $4.51 \%$ \\
\hline 2 & $1.29 \%$ \\
\hline 1 & $0.64 \%$ \\
\hline 18 & \\
\hline 10 & $6.45 \%$ \\
\hline 3 & $1.93 \%$ \\
\hline 3 & $1.93 \%$ \\
\hline 2 & $1.29 \%$ \\
\hline
\end{tabular}

Table.2 Distribution of drug resistance $n=155$

\begin{tabular}{l} 
Organisms \\
\hline MIDR \\
\hline Carbapenemase producer \\
\hline Non-fermenter Resistant to Colistin \\
\hline MIRSA
\end{tabular}

$\%$ of isolates

\begin{tabular}{|c|}
\hline$\%$ of isolates \\
\hline $62 \%$ \\
\hline $33 \%$ \\
\hline $3.3 \%$ \\
\hline $1.93 \%$ \\
\hline
\end{tabular}

MDR-Strain resistant to two or more group of antibiotics.

Carbapenemase producer-Strain resistant to Imipenem \& or Meropenem.

Table.3 Sample wise distribution of MDR isolates $n=155$

\begin{tabular}{|l|}
\hline Clinical sample \\
\hline Blood \\
\hline Urine \\
\hline Pus \\
\hline Body Fluids \\
\hline
\end{tabular}

\begin{tabular}{|l|l|}
\hline No. of MIDR organisms & $\%$ of MDR organisms \\
\hline 55 & $35.48 \%$ \\
\hline 25 & $16.12 \%$ \\
\hline 10 & $6.45 \%$ \\
\hline 3 & $1.93 \%$ \\
\hline
\end{tabular}

Antimicrobial resistance pattern

\section{Enterobacteriaceae}

\begin{tabular}{|l|}
\hline Antibiotics \\
\hline Cefepime \\
\hline Cotrimoxazole \\
\hline Cefotaxime \\
\hline Piperacillin + Tazobactam \\
\hline
\end{tabular}

\begin{tabular}{|l|}
\hline \% of resistance \\
\hline $88.75 \%$ \\
\hline $73.2 \%$ \\
\hline $64.7 \%$ \\
\hline $61.96 \%$ \\
\hline
\end{tabular}




\section{Non-fermenters}

\begin{tabular}{|l|l|}
\hline Antibiotic & $\%$ of resistance \\
\hline Cefepime & $84.4 \%$ \\
\hline Cefoxitin & $82 \%$ \\
\hline Cotrimoxazole & $77.6 \%$ \\
\hline Ceftazidime & $77.5 \%$ \\
\hline Cefotaxime & $72 \%$ \\
\hline
\end{tabular}

Gram positive cocci

\begin{tabular}{|l|l|}
\hline Antibiotic & $\%$ of resistance \\
\hline Penicillin & $80 \%$ \\
\hline Erythromycin & $40 \%$ \\
\hline Gentamycin & $30 \%$ \\
\hline Ciprofloxacin & $30 \%$ \\
\hline Tetracyclin & $30 \%$ \\
\hline
\end{tabular}

Septicemia (61\%) was the most common type of infection followed by urinary tract infections (23\%).

Majority isolates were Gram negative bacilli (88.4\%), among them $P$. aeruginosa was most common $(21.93 \%)$.

MDR isolates were $-62 \%$. Among them Carbapenemase producers were $33 \%$,

MRSA isolates were $1.93 \%$ and Nonfermenters resistant to colistin were 3.3\% .

Increasing drug resistant organisms emerging in health care settings is prolonging hospital stay and increasing the cost of health care.

So there is an urgent need to formulate guidelines and rationalize the use of antibiotics to curtail this pandemic of drug resistance.

\section{Acknowledgment}

Authors are thankful to entire Dept. of Pediatrics for sending all specimens and giving clinical history of patients.

\section{References}

Asensio A, Oliver A, Gonzalez-Diego P, Baquero F, Pe'rez-Diaz JC, Ros P, et al., Outbreak of a multi-resistant Klebsiella pneumonia strain in an intensive care unit: antibiotic use as risk factor colonization and infection. Clin Infect Dis 2000; 30:55-60.

Collee, J.G., Marr, W., Fraser, A.G. 2012. Mackie and McCartney's Practical Medical Microbiology. $14^{\text {th }}$ edition. New York: Churchill Livingston; 1996: p95-111.

Collee, J.G., Marr, W., Fraser, A.G. 2012. Mackie and McCartney's Practical Medical Microbiology. 14th edition. New York: Churchill Livingston; 1996: p113-129.

Dechen C. Tsering et al., Bacteriological profile of septicemia and the risk factors in neonates and infants in Sikkim. Journal of global infect Dis 2011; 3(1):42-45.

Douglas MW, Lum G, Roy J, Fisher DA, Anesty NM, Currie BJ. Epidemiology 
of community- accuired and nosocomial bloodstream infections in tropical Australia: a 12-month prospective study. Trop Med Int Health 2004; 9(7):795-804.

Forbes BA, Sahm DF, Weissfeld AS, editors. Bacterial Identification flow charts \& schemes: A guide to Part III. In: Bailey and Scott's diagnostic microbiology. $12^{\text {th }}$ edition Missouri: Mosby Elsevier; 2007. 251-253.

Forbes BA, Sahm DF, Weissfeld AS, editors. Bacterial Identification flow charts \& schemes: A guide to Part III. In: Bailey and Scott's diagnostic microbiology. $12^{\text {th }}$ edition Missouri: Mosby Elsevier; 2007. 260-283

Grisaru-Soen G, Sweed Y, Lerner-Geva L, Hirsh-Yechezkel G, Boyko V, Vardi A, et al., Nosocomial bloodstream infections in a pediatric intensive care unit: 3-year survey. Med Sci Monit 2007; 13: CR251-7.

Prasad Gunjal et al., A Cross-Sectional study to determine the profile antibiotic resistance pattern of gram negative bacilli isolated from intensive care unit patients in tertiary care hospital in Ahmednagar, Maharashtra.
International Journal of Biomedical and Advance Research. 2012; 03(05).

Ramesh Bhat $\mathrm{Y}$ et al., Early Onset of Neonatal Sepsis: Analysis of the Risk Factors and the Bacterial Isolates by Using the BacT Alert System. Journal of Clinical and Diagnostic Research. 2011 November (Suppl-2), Vol-5(7): 1385-1388.

Suchada Sritippayawan, Klaita Sri-Singh, Nuanchan Prapphal, Rujipat Samransamruajkit, Jitladda Deerojanawong. Multidrug-resistant hospital-associated infections in a pediatric intensive care unit: a crosssectional survey in a Thai university International Journal of Infectious Diseases (2009) 13, 506-512 hospital.

Sucu N, Caylan R, Aydin K, Yilmaz G, Aktoz B, Koksal I. Prospective evaluation of blood cultuers in medical faculty hospital of Blacksea Technical University. Mikrobiyoloji Bulteni 2005; 39: 455-64.

Uslan DZ, Crane SJ, Steckelberg JM, Cockerill FR, Sauver JL, Wilson WR, et al., Age- and sex-associated trends in bloodstream infection. Arch Intern Med 2007; 167: 834-39.

\section{How to cite this article:}

Archana Chintaman Choure, Vaishali B. Dohe, Swati S. Mudshingkar, Meghana S. Palewar and Renu R. Bhardwaj. 2018. "Multidrug Resistant Bacteria in Pediatric Patients: A Therapeutic Nightmare". Int.J.Curr.Microbiol.App.Sci. 7(10): 2392-2396.

doi: https://doi.org/10.20546/ijcmas.2018.710.277 